\title{
CRYPTOCURRENCY TECHNOLOGY OF LITECOIN FOR INVESTMENT AND BUSINESS TRANSACTIONS BASED ON ISLAMIC LAW PERSPECTIVE
}

\author{
Moh. Mardi ${ }^{1}$ \\ mohmardi17@gmail.com
}

\begin{abstract}
This study aims to determine the legal validity of Litecoin cryptocurrency technology in investment and business transactions from the perspective of Islamic law. The applied theory used is the business taxonomy of haram lidzatihi and haram lighairihi from the number of scholars reconstructed by Adiwarman Abdul Karim. This research is qualitative research that is library research from the sources of Al-Quran and Hadith and through qiyas from figh laws that have been qat'i. The results of this study show that Litecoin technology can indeed recognize as an excellent revolutionary technology. However, its use as an investment instrument contains elements of maysir (betting) and as an instrument for business transactions contains elements of gharar, and does not have sharia benefits, so that its legal status is haram.
\end{abstract}

Kata Kunci: Cryptocurrency, Litecoin, Investment, Business, Islamic law

\begin{abstract}
Tujuan dari penelitian ini untuk mengetahui hukum keabsahan teknologi cryptocurrency litecoin dalam transaksi investasi dan bisnis persepektif hukum islam. Teori terapan yang digunakan adalah taksonomi bisnis haram lidzatihi dan haram lighairihi dari jumhur ulama yang direkonstruksi oleh Adiwarman Abdul Karim. Penelitian ini merupakan penelitian kualitatif yang bersifat liberary research dari sumber Al-Quran dan Hadist serta melalui qiyas dari hukum-hukum fiqih yang sudah qat'i. Hasil dari penelitian ini bahwa teknologi Litecoin memang bisa diakui sebagai teknologi revolusioner yang sangat baik, namun penggunaannya sebagai instrumen investasi mengandung unsur maysir (pertaruhan) dan sebagai instrumen transaksi bisnis mengandung unsur gharar, serta tidak memiliki manfaat secara syariat sehingga setatus hukumnya adalah haram.
\end{abstract}

Kata kunci: Cryptocurrency, Litecoin, investasi, bisnis, syariat Islam

\section{Introduction}

Today's technological progress is extraordinary, including technological advances in the economic field. One of the spectacular technological advances in the economic field is the creation of cryptocurrencies or virtual money in cyberspace. There are many types of cryptocurrencies, including Ripple, Lisk, Ether, MaidSafeCoin, Litecoin, StorjCoinX, Ethereum, Dash, Monero, Zcash, and Bitcoin (BTC) (Brainytutorial, 2018). With virtual money now, business transactions can be done

1 STAI Syaichona Moh. Cholil Bangkalan

Volume 12 Number 2 October 2021 
online without involving middlemen such as banks. Transactions are carried out instantly, across countries, across continents, faster, easier, cheaper, and with more guaranteed confidentiality.

Litecoin has several advantages. Its main advantage is Blockchain technology. However, in addition to these advantages, there are several weaknesses, including that Litecoin virtual money does not have an underlying asset, is not controlled by the responsible authority agency (in Indonesia by the Financial Services Authority / OJK), so it is not safe, and without the clear name of the owner so that it is prone to be used as a means of crime. Litecoin's value goes up and down based on the laws of market demand and supply. When there is only a small amount of Litecoin in circulation to meet the needs while there is much demand, the price of Litecoin will increase.

According to Islamic law, the legality of the use of Litecoin and the law of its use in business transactions, there are still pros and cons (khilafiyah) among economists and scholars. This research is in the scientific framework of Technoculture. Technoculture is in between two scientific circles, namely technology on the one hand and culture on the other. In the middle, there is a wedge in religiosity values (religious values, beliefs, spirituality, humanity, and cultural civility values). In this research, the technology side is Litecoin cryptocurrency, especially Blockchain technology. The artistic side is the socio-economic effect of using Litecoin in business transactions, which disrupts the country's monetary system.

The purpose of this study is two fold: to find out an overview of Litecoin virtual money technology, especially the working pattern of Blockchain technology and the legal position of using Litecoin as an investment instrument and business transaction instrument according to Islamic law. So, there are two issues raised, namely about technology and secondly about this legal position: how is Litecoin cryptocurrency technology, especially about Blockchain working patterns? Moreover, what is the legal position of using Litecoin virtual money as an investment instrument and business transaction?

This issue concerns the interests of the broader community so that it has great significance for research. The results of this research theoretically will be an additional enrichment of research theory in Technoculture and become computational and 
SYAIKHUNA: Jurnal Pendidikan dan Pranata Islam STAI Syichona Moh. Cholil Bangkalan p-ISSN:2086-9088, e-ISSN: 2623-0054

DOI: https://doi.org/10.36835/syaikhuna.v12i2.5132

modelling material. As for practical use, this study's results will use as a shari'a guide for the community.

Based on the results of the preliminary study, there have been several previous studies conducted on Litecoin technology and research on the legal standing of Litecoin use. However, the two research objects are written separately, Litecoin technologists in one article, during the review of Islamic law in another article. Some of these writings include the following.

(1) Luqman Nurhisam from the State Islamic University (UIN) Sunan Kalijaga Yogyakarta, with an article entitled "Litecoin in the Eyes of Islamic Law" published in Ar- Raniry International Journal, Vol. 4, No. 1, June 2017 pages 165-186. The article describes the widespread use of Litecoin, and the use of Litecoin has more harm than benefits, so it is illegal (Hisam, 2017). (2) Mariske Myeke Tampi, lecturer at the Faculty of Law, Tarumanagara University, Jakarta, with the article title "Legal Protection for Litecoin Investors in Indonesia: to Move Beyond the Current Exchange System" published in the Journal of Law \& Development 47 No. 1 (2017) pages 83-99. (3) Wahyu Hidayat "Explanation

Chairman of the MUI Da'wah Commission on Litecoin's Legal Matters" explained that KH. Cholil Nafis argues that the existence of Litecoin as a new currency, namely virtual money, is not a problem because in the past, the caliph Umar ibn Khattab intended to make a new type of money from camel skin. Litecoin in business transactions tends to be illegal because the existence of Litecoin has not been recognized by the state (Hidayat, 2018). (4) Axel Yohandi, Nanik Trihastuti, and Darminto Hartono from the Faculty of Law, Diponegoro University researched the "Juridical Implications of Using Litecoin Virtual Currency as a Payment Instrument in Commercial Transactions (Comparative Study between Indonesia-Singapore)" The article published in the Diponegoro Law Journal Volume 6, Number 2, 2017. They explain the need for a legal umbrella for Litecoin (Aksel Yohandi, 2017). Matthew J.Martin from Blossom Finance, a fintech startup based in Indonesia, explained two essential things: (1) Litecoin currency is more lawful than conventional fiat money because conventional money in many countries is the result of usury loans. In contrast, Litecoin virtual money is not based on debt. Litecoin is based on proof of work, so it is categorized as not illegal; (2) Litecoin Blockchain technology is an excellent online 
payment system. It is easier, faster, cheaper, and more secure because it uses cryptography. This Litecoin goes beyond what conventional banking has to offer. So, Litecoin technology is very halal (Fulus.com, 2017).

This research has differences and novelty values when compared to previous research, namely (1) in terms of the object of research because this research is within the framework of Technoculture, the object of research is divided into two in a balanced way, namely the technology side of Litecoin itself and the legal review side according to Islamic law; (2) The legal isinbath used is not just qiyas but also mashalih al-mursalah;

The research approach is not just theological (Islamic fiqh) therefore, this research uses a transdisciplinary approach, namely the scientific-technology approach, the theological approach (Islamic law), and the philosophical approach (transcendental philosophy).

\section{Method}

This research uses grand theory, middle-range theory, and applied theory. In the book The Sociological Imagination (1959), published by Oxford University, Charles Wright Mills, an American sociologist, stated that grand theory is a term that refers to high abstraction theory as a concept of understanding the social world. In Mills' view, the grand theory is separate from the reality of everyday life, which varies widely and depends on space and time. So, the content of the grand theory is idealism that is universal and does not relate to facts in a very particular field. The middle range theory was developed by Merton (1968:39) as a social approach theory to integrate theory with field research. Furthermore, the middle-range theory is derived from applied theory. The applied theory is a theory that is directly used to dissect the problem under study, which is very particular.

In this study, the grand theory used is the theory of Maslahah Al-Mu'tabarah from the majority of scholars. According to this theory, the basic assumption is that Islam is rahmatan li al'alamin, namely mercy for all nature, for all humans. This benefit can be reached through the explanation of the reason or obtained through the work of reason. The benefit or not of something return to the five functions of religion, namely hifdzu dien (maintaining religion), hifzdu al-Nafs (maintaining the soul), hifdzu al-aql 
SYAIKHUNA: Jurnal Pendidikan dan Pranata Islam STAI Syichona Moh. Cholil Bangkalan p-ISSN:2086-9088, e-ISSN: 2623-0054

DOI: https://doi.org/10.36835/syaikhuna.v12i2.5132

(maintaining reason), hifdzu al-nasab (maintaining offspring), and hifdzu al-nasab.al-maal (keeping property). Those are the five pillars of life. Humans cannot live well without these five pillars (Zahrah, $1427 \mathrm{H} / 2006 \mathrm{M}$ ).

This research is qualitative, which has naturalistic characteristics (natural), analytical descriptive (as it is and analyzed), prioritizes processes (meaning analytical and reflective critical thinking processes), inductive (starting from general things to specific things), and attention to meaning (meaning and interpretation are a necessity for qualitative research. This research is library research). The data sources include the Alquran, hadith, books, other printed materials, and online media.

\section{Results and Discussion}

\section{Cryptocurrency Litecoin}

The existence of Litecoin: Aleksander Berentsen and Fabian Schar, in their article "A Short Introduction to the World of Cryptocurrencies", published in the Federal Reserve Bank of St. Louis Review, asserts, Litecoin is virtual money that has no concrete object (Aleksander Berentsen, 2018). According to Nakamoto, Litecoin is a purely peer-to-peer version of electronic cash that would provide online payments to be sent directly from one party to another without going through a financial institution. Litecoin is an online payment system of peer-to-peer (P2P) electronic cash sent directly from one party to another without going through a financial institution (Nakamoto, Litecoin.org, 2018). Litecoin is money belonging to the world, not belonging to any particular country.

Blockchain Technology: Litecoin holdings and transactions are protected by Blockchain technology. A blockchain is computer software that contains a database and functions as a world accounting ledger with a computer system distributed throughout the Litecoin user computer network in a peer-to-peer manner following an agreed protocol. Peer-to-peer is connecting from one computer to another in an extensive network of all Litecoin users. After the transaction data is recorded and sent, the data cannot be changed because all blocks must carry out data changes. This is not easy because when changing requires the agreement of all network users. Blockchain records the chronological history of all transactions that have occurred in a series of blocks connected. Thus, transactions with Litecoin virtual money are essentially a 
SYAIKHUNA: Jurnal Pendidikan dan Pranata Islam STAI Syichona Moh. Cholil Bangkalan p-ISSN:2086-9088, e-ISSN: 2623-0054

DOI: https://doi.org/10.36835/syaikhuna.v12i2.5132

secret signature chain. According to Satoshi, cooperation between Litecoin users using cryptography will defeat the attackers (Nakamoto, Litecoin.org, 2018).

Blockchain working pattern: Nakamoto explains the Blockchain working steps as follows. (1) Every time a new transaction occurs, it will be broadcast on all nodes in a peer-to-peer manner; (2) Node will collect all new transactions into a block; (3) All nodes will validate the transaction for their block. It is a difficult job; (4) When successfully validating a transaction or finding proof of work, the block will broadcast to all nodes; (5) The node receives evidence if the Litecoin has no use. Therefore, there will be no double-spending; (6) The node declares the acceptance of the block and then creates a new block (Nakamoto, a Peer-to-Peer Electronic Cash System, 2016).

\section{Legal Position of Using Litecoin Virtual Money as an Investment Instrument} and Business Transaction According to Islamic Shari'a

First, the foundation of the Alquran. Two verses are used as the basis for discussing the legal use of Litecoin, both as an investment instrument and as an instrument for business transactions, namely the letter al-Nisa [4] paragraph 29 and surah al-Maidah [5] verse 90. Allah SWT says: "O you who believe, do not eat each other's property in a vanity way, except in trade that occurs based on consensual between you. Moreover, do not kill yourself. Indeed, Allah is Most Merciful to you (KSA, 2001). "O you who believe! Verily, drinking liquor, maysir (gambling), (sacrificing) to idols, and drawing lots of luck with arrows are heinous acts and are included in the devil's actions. So stay away from those (actions) so that you are lucky" (KSA, 2001). From these two verses, two keywords can be interpreted, namely the word basil and maysir.

\section{The study of the interpretation of the vanity keyword.}

- Imam al-Ashfahani, in his book al-Mufradat fi Garib al-Quran page 56, explains that the word batil comes from bathala - yabthulu 'broken', 'false', or 'invalid'. As for the term, vanity is al-batil naqidlun al-haqqi wa hua ma la tsabata lahu 'inda al-fahsyi 'anhu (Asfahani al, 2012). Vanity is the opposite of the truth, that is, things that are not fixed when examined.

According to Isnawy in the book Al-Tamhid fi Tahrij al-Furu' 'ala al-Ushul page 55 , some scholars state that the words batil and facade are the same, but according to 
SYAIKHUNA: Jurnal Pendidikan dan Pranata Islam STAI Syichona Moh. Cholil Bangkalan p-ISSN:2086-9088, e-ISSN: 2623-0054

DOI: https://doi.org/10.36835/syaikhuna.v12i2.5132

Abu Hanifah, the two words have differences. The word batil is something that violates the Shari'a in total, such as selling an animal in the womb. In contrast, the word 'broken' facade is initially allowed and then prohibited because there are other factors that violate the Shari'a, for example, usury (Al-Isnawy, $1980 \mathrm{M} / 1400 \mathrm{H}$ ).

- Abdul Karim Zaidan in the book al-Wajiz fi Ushul al-Figh, page 65 explains af 'al al-mukallafina idza waqa'at arkanuha wa syuruthuha (Zaidan A. K., 2006 M/1427 H). The act of mukkallaf (a person who is subject to a burden) is only judged as a legally valid act if the activity meets the requirements and pillars. This also applies to contract acts. In this case, the scholars divide the contract into two, namely a valid contract and a valid contract. One of the contracts that are not valid is a false contract. A batil contract is a contract that does not meet the requirements and is in harmony.

- Wahbah Zuhaily, in the book of commentary on al-Munir juz V pages 30-31, explains bi al-batili aw bi al-haram fi al-syari' ka al-riba wa al-qimar wa al-ghasab, using vanity, using prohibited by the Shari'a, such as usury, lottery gambling, and corruption. Batil in business transactions is kullu ma yu'khadzu 'audhan 'an al-uqudi alfasidah aw al-batilah, namely everything that is included in the damaged and void contract (Zuhaily W., 1998 M).

- Jaluddin al-Suyuthy, in his book commentary on the Al-Quran Jalalain explains that bi al-batili is bi al-haram fi al-Syar'i ka al-riba wa al-ghashab, batil is shari'a haram such as usury and corruption (Jalalain, 1991M/ 1412 H.).

- Al-Shabuni in the book of Shafwah al-Tafasir page 271 explains al batili hua kullu tariqin lam tabhahu al-syariatu ka al-sirqati wa al-khiyanah wa al-ghasab wa al-riba wa al-qimar wama syakilun dzalika, vanity is any path that is not permitted by syara, such as stealing, treason, corruption, usury, gambling, and the like (Al-Shabuni, 1976 M.1306 $\mathrm{H})$.

Based on this, a batil contract is a damaged and invalid contract. It can be invalid because of the essence or other factors, such as usury, corruption, betrayal, and gambling. Another thing to note is that between taradhin or rida and rida, while rida is a secret and hidden job. Therefore, for the attitude of rida to be known, there needs to be consent and acceptance in every business transaction. The study of maysir interpretation. 
SYAIKHUNA: Jurnal Pendidikan dan Pranata Islam STAI Syichona Moh. Cholil Bangkalan p-ISSN:2086-9088, e-ISSN: 2623-0054

DOI: https://doi.org/10.36835/syaikhuna.v12i2.5132

- Muhammad Quresh Shihab, in the interpretation of Al-Misbah volume 3, page 236, states, maysir comes from the word just, which means easy. For a person who gambles, it is easy to get wealth but also easy to lose his property (Quraish, 2002).

- Al-Shabuni in the book Tanwir al-Adzhan min commentary Ruh al-Bayan Volume I page 442 explains, al-maysir ae alqimar kulluhu fayadkhulu fihi al-Nardu wa alsyithranji wa ghairu dzalika mimma yuqamiruna bih. Maysir is all forms of gambling, including playing dice and chess, commonly used for betting (Shabuni al M. A., 1991 M, 1409 H).

- Wahbah Zuhaily in the book of Tafsir al-Munir fi al-Aqidah wa al-Syariah page 39 explains, al-maysir kullu sayiin min al-qimar hatta la'bu shibyani bi al-jawzi, maysir is every lottery game even if it is a children's game with nutmeg, as the Prophet's hadith received by Ali Ibn Abi Talib. Al-Syithranju min al-maysr (Zuhaily W., Tafsir al-Munir fi al-Aqidah wa al-Syariah wa al-Manhaj, 1998 M/1418 H.)

Adiwarman Abdul Karim thinks that maysir is a game if one party bears a loss to the other party due to the game (Karim A. A., 2010). In essence, maysir includes gharar because there is ambiguity and chancy or high speculation/gambling (Karim A. A., 2010).

Second, the basis of the hadith of the Prophet Muhammad. The hadith accepted by Abu Hurairah is as follows. 'An Abi Hurairah ra qala, naha Rasulullah SAW 'an ba'i al-hashat, wa 'an ba'i al-gharar (HR. Muslim) as stated in Sahih Muslim chapter 4 hadith number 1513. Abi Hurairah said, Indeed, the Messenger of Allah (PBUH) forbade the buying and selling of al-hashat, namely by throwing, and buying and selling al-gharar, containing an element of obscurity. Second Hadith from Ibn Masud. 'An Abi Masud, anna nabiyya sallallaahu 'alaihi wa sallam qala la tasytaru al-samaka fi al-mai fa innahu gharar.' Imam Ahmad narrated this hadith in Sunan Ahmad, volume 1 page 388. It means, from Ibn Mas'ud. Indeed the Prophet SAW said, do not buy fish in the water because it is gharar. Imam Shan'ani explains in the book Subul al-Salam volume III, page 21 that Al-gharar is al-khatr or betting and al-khida' or fraud (Shan'ani, 1420 H/1999 $\mathrm{AD})$.

Imam al-Syaukani, in the book Nail al-Authar volume III page 516, also explains that gharar business transactions include buying and selling fish in the water, buying and selling birds in the air that have not been caught, buying and selling milk 
SYAIKHUNA: Jurnal Pendidikan dan Pranata Islam STAI Syichona Moh. Cholil Bangkalan p-ISSN:2086-9088, e-ISSN: 2623-0054

DOI: https://doi.org/10.36835/syaikhuna.v12i2.5132

that is still in the animal's body, and buying and selling goats that are still in the womb. Buying and selling are said to be gharar because of the uncertainty in both quantity and quality. These two traditions were quoted by Imam al-Syaukani when explaining Bab al-Nahyu 'a Buyu' al-Gharar. The chapter discusses the prohibition of buying and selling gharar (Syaukani al, 2000 AD/1420 AD). Shaykh al-Islam Ibn Taimiyah stated, something is called gharar because the outcome cannot be predicted (majhul alaqibah). Wahbah Zuhaily, a contemporary scholar, when elaborating about gharar transactions in the book of al-Fiqh wa Adillatuh he quoted the opinion of several imams, including Imam al-Shirazi al-Syafii in the book of al-Muhadzdazb volume I page 262, stating, gharar is a transaction which results are vague (Zuhaily W. , Al-Fiqh al-Islamy wa Adillatuh, vol. V, 1997 AD/1418 H)

Imam Asnawy al-Shafii, in the book Al-Manhaj al-Ushul II, page 89 states, gharar is a transaction whose consequences are between profit and loss. Meanwhile, Ibn Hizam in the book of Al-Muhalla juz 8 page 369 states "al-gharar ma la yadri almusytari ma ashtara, aw al-ba'i ma ba'a (gharar transactions are transactions if the buyer does not know what he buys, or the seller does not know what he is selling (Hizam, tt). Based on these several definitions, Wahbah al-Zuhaily formulated, gharar transactions are transactions in which it is not healthy, such as selling milk that is still in the body of a cow, selling pearls that are still at the bottom of the ocean, selling young goats that are still in the womb, or selling birds in the air before they are caught (Shan'ani, 1420 H/1999 AD).Imam Al-Mawardi provides a more measured definition of gharar, namely wa haqiqatu al-gharari fi al-bai'i ma taraddada baina jaizaini akhwafuhuma aghlabuhuma. Thus, the essence of gharar in buying and selling transactions is a situation with two possibilities, but the lousy possibility has the opportunity. (Skolahoke.com, 2012). Transactions that contain elements of gharar are vanity, forbidden, and unlawful lighairihi. According to Imam Nawawy, gharar transactions are a matter of ushul (principal), whereas, in everyday life, these buying and selling activities are very numerous and often occur.

\section{Litecoin Qiyas Law}

Ibn Taimiyah, in his Majmu' Fatawa juz 8, explains the logic of law, al-hukmu a'la syai-in far'un 'an tashawwurihi, the law of everything derive from how one sees it (Taimiyah, 2004). The qiyas method will project on Litecoin. The application of the law 
to the Litecoin case is likened to the case of selling fish in water, namely (1) Al-ashl is buying and selling fish in water; (2) The furu' is buying and selling Litecoin virtual money in cyberspace; (3) The law of authenticity is that it is forbidden to buy and sell fish in the water; (3) 'illat or similarity in nature, namely buying something that is not clear, both in quantity and quality of goods. Thus, buying and selling Litecoin is the same as buying and selling fish in water, which both contain the element of gharar. Therefore, having the same law is haram.

The law of selling fish in water is haram because it contains ambiguity (gharar). Fish in the water, the shape of the fish in the water is unknown, the kilograms and the number of fish in the water are unknown. Meanwhile, the buyer must pay a predetermined amount of money. That is not fair. The above case has similarities with Litecoin sales. Litecoin is imaginary money, a delusion, a dream, but sold for an exact price. Thus, selling Litecoin is illegal.

The same goes for the Litecoin exchange rate. The rise and fall of the exchange rate of money in a country depending on the value of the country's imports and exports. When the value of exports increases, the exchange rate increases. Conversely, if the value of exports decreases, the value of the country's money also decreases. This is different from the case of Litecoin. The rise and fall of the Litecoin exchange rate are not related to the value of imports and exports but depends on public opinion built into the marketing system. Litecoin does not have an underlying asset, so Litecoin exchange rate fluctuations are very extreme. Litecoin can skyrocket and fall sharply, making it difficult to predict. Therefore, this Litecoin business is like betting. This is the element of maysir. Thus, the prohibition of using Litecoin virtual money as an investment instrument and business transaction is haram lighairihi or haram because other factors are outside of substance.

\section{Conclusion}

The existence of Litecoin as a virtual currency is considered legal, legal, or allowed under several conditions, namely if the state recognizes it. This is because the rights and obligations to manage iqtishadiyah, including the issuance of new currencies, are the state's authority. This was based on the caliph Umar bin Khattab (head of government) to make a new type of currency from camel skin. In this case, 
SYAIKHUNA: Jurnal Pendidikan dan Pranata Islam STAI Syichona Moh. Cholil Bangkalan p-ISSN:2086-9088, e-ISSN: 2623-0054

DOI: https://doi.org/10.36835/syaikhuna.v12i2.5132

Litecoin is not issued by the state and is not recognized by Bank Indonesia, so Litecoin is a currency that is not considered legal in Indonesia. Bank Indonesia (BI) and the Financial Services Authority (OJK) are not responsible for any problems caused by the use of Litecoin, either as an investment or as a means of business transactions.

The Litecoin cryptocurrency uses a revolutionary technology called Blockchain. Blockchain is computer software that contains a database of all online payment transactions across countries, across continents, more accessible, faster, cheaper, and more confidential. Transaction data is automatically disseminated in a peer-to-peer manner throughout the Litecoin user's computer network worldwide to be known and controlled by the public. Blockchain technology also functions as a safeguard against counterfeiting attempts and serves to prevent double-spending. Blockchain technology is a revolutionary online payment technology that exceeds expectations, far better than the financial technology used by the banking world. This is not against Islam and even supports a futuristic online payment system. Thus, it is lawful.

Litecoin as an investment instrument and business transaction contains maysir because it contains high speculation and is chancy, so BANK Indonesia calls it a gambling transaction. This is more difficult than playing foreign exchange (forex) because the foreign exchange has underlying assets and a guarantor authority agency. In this regard, the use of Litecoin as an investment instrument is haram lighairihi, or haram, due to external factors (gharar and maysir).

The use of Litecoin in business transactions is analyzed using qiyas. Litecoin is qiyased by buying and selling fish in the water. Both have illat or similar characteristics, namely gharar or contain obscurity. Moreover, Litecoin as imaginary money has many obscurities. Thus, the use of Litecoin in business transactions, the law is haram lighairihi (haram because there are external factors, namely gharar).

\section{REFERENCES}

Adityo, N. P. (2017, Desember 20). Mengenal transaksi Litecoin dalam perspektif islam. Retrieved From http://www.Republika. coid/berita/jurnalismewarga/ wacana/17/12/20/p19aOd396- mengenal-transaksi-Litecoin- dalamperspektif-islam. 
SYAIKHUNA: Jurnal Pendidikan dan Pranata Islam STAI Syichona Moh. Cholil Bangkalan p-ISSN:2086-9088, e-ISSN: 2623-0054

DOI: https://doi.org/10.36835/syaikhuna.v12i2.5132

Agustri. (2012). Pengertian, hukum, dan contoh jual beli tidak jelas (gharar) haram, atau halal Retrieved from http://www sekolahoke.com/2012/Gharar- Dalam-JualBeli.html

Aksel Yohandi, N. T. (2017). Implikasi yuridis penggunaan mata uang virtual Litecoin sebagai alat pembayaran dalam transaskis komersial. Diponegoro Law Journal volume 6 nomor 2, 83-99.

Al-Shabuni, a. M. (1976 M.1306 H).

Shafwah al-tafasir. Beirut: Dar Al-Qalam.

Andreas, D. (2018). Jakarta: https/tirto. id/kajian-bappeti-soalnbsLitecoin- berlanjutmeski-bi-larang-uang- digital.cDF2.

Asfahani al. (2012). Al-mufradat fi gahrib al-quran. Kairo: Dar ibn Jauzy.

Assimalhakeem. (2017, Februari 01). Is Litecoin halal in islamic point or vew.

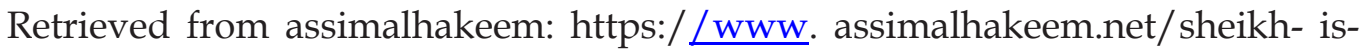
Litecoin-halal-in-islamic- point=or-view /

Ausop, A. Z. (2014). Islamic character building, membangun muslim cendekia berakhlak qurani. Bandung: Grafindo, Salamadani.

Bais, A.N. (2018). Litecoin itu Dilarang - Koreksi Artikel Litecoin Retrieved https:/ / konsultasisyariah.com/31095- Litecoin-itu-dilarang-koreksi-

artikel-Litecoin.html

Berentsen, A. F. S. ( 2018, First Quarter). A short introduction to the world of cryptocurrency. Retrieved from Federal Reserve Bank of Louis Review: https: // doi. org/10.20955/r.2018.1-16

Biggs, T. (2015). Litecoin's mysterious

creator satoshi nakamoto could be australian man craig steven wright: Report. Retrieved from https://www.smh.com.au/ technology/Litecoins-mysterious- creatorsatoshi-nakamoto-could- be-australian-man-craig-steven- wright-report20151209-glixin. html

Brainytutorial. (2018, Januari 20). Macam-macam uang digital. Retrieved from Brainytutoral: https:// www.brainytutorial.com/ macam-macam-mata-uangdigital-cryptocurrency/ 
SYAIKHUNA: Jurnal Pendidikan dan Pranata Islam STAI Syichona Moh. Cholil Bangkalan p-ISSN:2086-9088, e-ISSN: 2623-0054

DOI: https://doi.org/10.36835/syaikhuna.v12i2.5132

DeVries, P. D. (Oktober 2016). An analisys of xryptocurrency, Litecoin, and future. International Journal of Bussiness Management and Commerce, Vol I nomor 2 September 2016, 1.

Fulus.com. (2017, Maret 15). Apakah Litecoin halal. Retrieved from www.fulus.com: www.fulus.com/ forum/threads/apakah-Litecoin- halal-bagaimanacryptocurrency- dalam-islam-dan syariah.3076/

Gontor, T. (2006). Ushul figh. Ponorogo: Pondok Pesantren Modern Gontor.

Hitu, M. H.-A. (1980 M/1400 H). al- tamhid fi takhrij al-furu' 'ala al-ushul dari imam jamaluddin abi muhammad adirrahman bin al-hasan al-isnawy. Beirut: Mansyurat Muassasah al-Risalah.

Hisam, L. (2017). Litecoin dalam kacamata hukum islam. Ar-Raniry Journal Internasional volume 4 No. 1 Juni 2017, 165-186.

Hizam, i. A. (t.t). Al-muhalla, jilid v, juz 8,. Beirut: Dar al-Fikri.

Hudhary Bek, S. M. (2005 M/1426 H.). Ushu figh. Beirut Libanon: Dar al-Kitab alAraby.

Isnawy, J. A.-H. (1980 M/1400 H). al- Tamhid fi takhrij al-furu' 'ala al-ushul dari imam jamaluddin 